\title{
Learning huddles: absorptive capacity and sustainable growth of Chinese incubatees
}

\author{
Geraldine Kennett \\ La Trobe Business School, La Trobe University, \\ Bundoora, Australia \\ Ling $\mathrm{Hu}$ \\ School of Economics and Management, University of Science and Technology, \\ Beijing, China, and \\ Alex Maritz and He Sun \\ La Trobe Business School, La Trobe University, \\ Bundoora, Australia
}

\begin{abstract}
Purpose - This study explores the different learning practices of Chinese incubators in Chongqing and Chengdu and delves into how these "learning huddles" influence incubatees' absorptive capacity (the ability to apply knowledge) to improve their chance of success (sustainable growth).

Design/methodology/approach - This explorative study uses a qualitative case study approach by means of semi-structured interviews with business incubation managers and incubatees across three business incubators in Chengdu and Chongqing. The data are transcribed, coded and analyzed using an analytic map for the explanation of building and reflecting on the theoretical propositions, leading to a further understanding of the "learning huddle" mechanism.

Findings - The study finds that incubatees perceive that their absorptive capacity is increased through vicarious informal learning practices that promote access to networks and thereby builds social capital to improve their likelihood of success.

Research limitations/implications - This study has limitations in sample size and design. The explorative case study approach uses a nonrandom case selection of three incubators in Chongqing and Chengdu and has a limited number of interviewees, which may lack representation of the general Chinese business incubation population and may not sufficiently be generalized beyond the sample itself.

Practical implications - These findings have important implications for business incubation programs. Business incubators that build learning huddles (networks) create a nurturing shared learning environment, which is suitable for incubatees to collectively absorb knowledge at the early stage of their life cycle and improve their likelihood of sustainable growth.

Social implications - Since this study is limited to a Chinese context, it is also hoped that future researchers use the typology of business incubator learning practices to explore cross-culture variables, as these may influence the business incubation operations and performance.

Originality/value - This study adds to the discussion on how collective learning practices facilitate absorptive capacity and build social capital, which in turn improves incubatees' chance of sustainable growth and as such the authors hope that the learning practice's typology and how incubatees determine their success stimulates further research for measuring the likelihood of incubatees sustainable growth.
\end{abstract}

Keywords Learning, Absorptive capacity, Social capital, Sustainable growth, Business incubator, Incubatee Paper type Research paper

(C) Geraldine Kennett, Ling Hu, Alex Maritz and He Sun. Published in Journal of Industry-University Collaboration. Published by Emerald Publishing Limited. This article is published under the Creative Commons Attribution (CC BY 4.0) licence. Anyone may reproduce, distribute, translate and create derivative works of this article (for both commercial and non-commercial purposes), subject to full attribution to the original publication and authors. The full terms of this licence may be seen at http:// creativecommons.org/licences/by/4.0/legalcode.
Learning huddles 


\section{JIUC 2,3}

\section{Introduction}

As innovation and entrepreneurship become critical to the process of economic and regional development, many forms of incubation organizations have emerged, including business incubators, coworking spaces, start-ups and accelerators (Cohen et al., 2019; Kahrović, 2020). Although business incubators have become an integral part of the modern entrepreneurial ecosystem according to the National Bureau of Statistics of China (2020), China's gross domestic product (GDP) growth of business incubators has reduced below 7\% since 2015, making small- and medium-sized enterprises' survival more difficult. Therefore, the continuous establishment and investment in incubator programs that offer facilities, shared resources and business training of start-up organizations are imperative (Zhang et al., 2017).

Due to the critical function of business incubators in nurturing and promoting new firms in their early stage, many studies have been conducted to determine the models of business incubation process (Hackett and Dilts, 2004; Hausberg and Korrek, 2020; Tang et al., 2019), the impact of business incubators on economic development (Peters et al., 2004; Bergek and Norrman, 2008; Haugh, 2020), the effectiveness of assessment of business incubation success (Dee et al., 2011; Kiran and Bose, 2020) and the key position of incubator manager in the incubation process (Hackett and Dilts, 2004; Kakabadse et al., 2020). Since incubatees are in the early stage of development, their knowledge, skills and experience are limited; therefore, it is worthwhile to systematically explore varying learning practices to identify how to facilitate the incubatees' sustainable growth (Wu et al., 2020). Furthermore, there is a lack of exploration into how knowledge flows in the business incubator context (Pettersen et al., 2015; Rubin et al., 2015).

Based on the critical function of business incubation to knowledge creation, this study explores and adds to the evolution of learning practices in Chinese incubators and delves into how these "learning huddles" influence incubatees' absorptive capacity (ability to add value, assimilate and apply new knowledge) to improve their chance of sustainable growth. Huddle, in this paper, refers to the phenomenon that incubatees gather together purposely in the incubator to learn, develop and grow their new ventures. By huddling together, incubatees may improve their capability to develop faster and go to the market earlier.

The next section reviews the literature on business incubator modes of learning, factors influencing incubatees' absorptive capacity and sustainable growth as an indicator of incubatees' success. This is followed by an explanation of the research design and methodology, the key findings and finally a discussion on the implications, limitations and possible future research options.

\section{Literature review}

The literature review goes from the broader context to the more specific by examining the past literature on learning practices in business incubators and then focusing on the adsorptive capacity and incubatees' sustainable growth. The first area of literature explores how firm-based learning typologies are used as a starting point to discuss learning practices in business incubators. The second area of literature, absorptive capacity, investigates the literature relating to how incubatees' value, assimilate and apply new knowledge and concludes with studies that relate to absorptive capacity's contribution to sustainable growth. The third part, incubatees' sustainable growth, explores whether studies reveal propositions on the relationship between learning practices, absorptive capacity and incubatees' sustainable growth.

\subsection{Business incubator modes of learning}

Firm-based learning is the term used to describe the process of acquiring skills and knowledge as well as changing behavior in an organizational context. In this context, 
common firm-based learning mechanisms are labeled as formal or informal (Cully, 2005; Kennett, 2013). Where formal learning is planned in advance and has a defined curriculum with structured training formats, such as seminars, lectures, workshops, audio-visual presentations, apprenticeships and traineeships. In contrast, informal training is unplanned and easily adapted to situations and individuals, and employees learn by observing others, doing the job or one-on-one with co-workers (Kennett, 2013; Myers et al., 2014). Manuti et al. (2015) express that organizations cannot rely on one learning mechanism and thereby firmbased learning achieves better results when structured formal learning is coupled with conditions to improve informal learning.

Business incubators are natural learning huddles. Business incubator learning practices expand on the firm-based learning typologies by emphasizing knowledge and skill acquisition through experiential learning (learning by doing), vicarious learning (learning from others), searching and noticing (increasing knowledge by scanning the internal and external environment) and social (learning through networks) (Pettersson and Götsén, 2016; Rae, 2000). In regard to Chinese incubatee learning practices, Zheng et al. (2017) indicate that incubators largely provide structured formal learning where knowledge is passively transferred by using cognitive focused classroom experience. The scholars recommend a shift to experiential reflection and vicarious learning to improve the incubatee know-how experience. This is because vicarious learning can facilitate input factors from a variety of sources such as customers, suppliers, competitors, research and development institutions and governmental bodies (Pettersen et al., 2015). And in this way, the incubatees have the ability to learn from experience driven by the collective sources (McCarthy and Garavan, 2008). However, there little there little research into collective learning in business incubators; hence, little is known about the value of collective learning for start-ups (Pettersson and Götsén, 2016; Cantù, 2017; Rubin et al., 2015).

P1. A typology of learning practices is useful as a mechanism for further studies in business incubators.

\subsection{Influencing factors of incubatees' absorptive capacity}

The concept of absorptive capacity was first introduced into the field of management by Cohen and Levinthal (1990), defined as "an ability to recognize the value of new information, assimilate it and apply it to commercial ends". Since then, this concept has been adopted widely to explore how organizations acquire knowledge and exploit learning (Szulanski, 1996; Lane and Lubatkin, 1998; Zahra and George, 2002), how to explain the mechanism of innovation context (Lane et al., 2001; Tsai, 2001) and how organizations improve performance and competitive advantage (Lane et al., 2001; Zahra and George, 2002; Ferreras-Mendez et al., 2015). From the perspective of firm level, absorptive capacity develops overtime by accumulating knowledge from collective members and is thereby affected by the prior investment in the development of individuals (Cohen and Levinthal, 1990).

A comprehensive study by Volberda et al. (2010) reveal four types of antecedents of absorptive capacity: managerial experience, intraorganizational, interorganizational variables and prior related knowledge. Managerial precursors are made up of the firm's combined managerial capabilities, management cognition and individual managers knowledge development and sharing. Intraorganizational precursors include the organization's form, structure and internal networks, whereas interorganizational includes knowledge sharing with external organizations through alliances and external networks (Volberda et al., 2010). Firms build experience by exposure to particular skills and capabilities (Hedberg, 1981), as well as through interactions with customers or competitors in the market and also learn by doing (Levitt and March, 1988). Van Wijk et al. (2008) also found that the breadth and depth of knowledge exposure brought positive influence on a firm's tendency to 

JIUC
2,3

144

learn related new knowledge. Therefore, diverse external knowledge existing among business partners or incubatees could be a precursor to absorb new knowledge and skills along with the past related experience.

Doing business in China often relies on developing and maintaining effective formal or informal relationships with relevant individuals or organizations (Choi and Jin, 2015), since this networking is vital to access key resources and knowledge sharing. Such social networks are common in incubators because of incubatees' shared spaces, technologies and other resources from the incubator (Schwartz and Hornych, 2010). And according to Hansen et al. (2000), social networks in incubators facilitate the formal and informal communication associated with incubation success, and social networks firms can build social capital and share knowledge more effectively (Belso-Martinez et al., 2013). In fact, social capital consists of all the social relationships available to access information and know-how (Uzzi, 1996) and can influence the ability to value, assimilate and apply new knowledge (absorptive capacity) and thereby sustain growth.

Also, a strong learning intent increases the probability of individuals' and firms' willingness to learn from alliances and external partners (Kim and Inkpen, 2005) and adopt a partner's skills and competencies (Simonin, 2004). In the context of incubators, strong learning intent may lead to increased motivation to learn. Therefore, learning intent of incubatees is a critical influencing factor of absorptive capacity. Hence,

P2. Absorptive capacity of incubatees is influenced by their experience, social networks and learning intent.

\subsection{Absorptive capacity and sustainable growth}

Ebersa and Maurerb (2014) propose that an organization's absorptive capacity has direct positive effects on firm success when knowledge is shared via alliances, joint ventures and research and development collaborations, especially concerning new products and advanced technologies (Bierly et al., 2009; Jiang and Li, 2009). As a type of dynamic capability, absorptive capacity leads to knowledge creation (Zahra and George, 2002), competitive advantage and above-average returns (Narasimhan et al., 2006).

Cohen and Levinthal (1990) suggest that lack of absorptive capacity may hinder the effectiveness of knowledge transfer, as absorptive capacity would then be based on current knowledge stock and not based on the accumulation of knowledge. Szulanski (1996) and Gupta and Govindarajan (2000) also propose that the absorptive capacity of the recipient firm is one of the most crucial deciding factors in the knowledge transfer process of multinational corporations. Therefore, in relation to this study, if an incubatee lacks absorptive capacity, it may not be capable of exploiting the necessary knowledge it needs for business development and sustainable growth. Hence,

P3. Absorptive capacity facilitates positive effects on the sustainable growth of incubatees.

\subsection{Sustainable growth as an indicator of incubatees' success}

It is difficult to measure incubatee success because business incubation is a complex process with multiple actors and actions involving business owners, managers of incubators, funders of incubation programs, community organizations, business mentors and finance companies (Bearse, 1998; Bøllingtoft and Ulhoi, 2005). Some studies use commercial measures such as sales growth, cash flow growth, assets growth and growth in the number of employees (Vanderstraeten and Matthyssens, 2010). However, not all entrepreneurial ventures are geared toward commercial outcomes (Moss et al., 2011). Organizations pursuing nonprofit ends articulate a value framework oriented toward societal impact, not just financial 
achievement (Taneja and Chenault, 2019). Also, Miettinen (2016) suggests that the measures of incubatee success have been mixed and even contradictory due in part from not taking into consideration the goals and strategies of incubatees.

Other studies indicate that incubatees' graduation from an incubator is an important indicator for evaluating the success of an incubatee. According to Burnett (2009), after a period of time (likely to be at least three years), the business graduates from the incubator into the surrounding business economy. However, graduating from the incubator may not be an indicator of sustainable growth in a highly competitive market environment. Where previously sustainable growth has meant the achievable growth that a company could maintain without running into problems (Baral, 2013), and it has been more recently defined as growth that is repeatable, ethical and responsible to current and future communities (Miller, 2018). Despite the lack of consensus for defining and measuring sustainable growth, an incubatee may perceive their success by a combination of survival, growth and profitability (Pettersson and Götsén, 2016).

An alternative theory of business incubation success is the function of networking and social interaction in incubators using either the term social capital theory or social network theory. Bøllingtoft and Ulhoi (2005) describe the success of business incubation, stating that it is "...being composed of individual and collective social networks, ties and structures that help the individual get access to information and knowledge" (p. 273). The social network theory acknowledges the role of social dimensions within economic relationships. The social network theory also identifies the role of an incubator in developing the entrepreneur's network in respect to gaining access to knowledge and resources in order to support sustainable growth (Peters et al., 2004). McAdam and McAdam (2008) argue that the relationships between start-ups result in synergies and social capital. These elements can aid the development of innovative capability, open up collaborations (Hansen et al., 2000) as well as the exchange of resources, information and knowledge (Böhringer, 2006; Bøllingtoft, 2012). All effects that, in theory, should help start-ups to survive and grow during their vulnerable phases (McAdam and McAdam, 2008) and the amount of social capital surrounding the incubatee are an indicator of success (Bøllingtoft and Ulhoi, 2005). Bliemel et al. (2019) further elaborate on how accelerators can perpetuate a virtuous cycle of developing community capitals, where success is improved by like-minded cohorts celebrating milestones and regularly inspiring each other to aim higher.

Given that incubatees are in the start-up phase of their new veneers, this study explores the incubatees' perceived fulfillment of planned goals and strategies, along with their development of social capital as measures for sustainable growth. And based on the above literature review, a theoretical framework concerning learning "huddles" was posited (See Figure 1).

\section{Research methodology}

Using a case study approach, the research aimed to uncover information about the transfer of knowledge in business incubators from the point of view of those who manage and

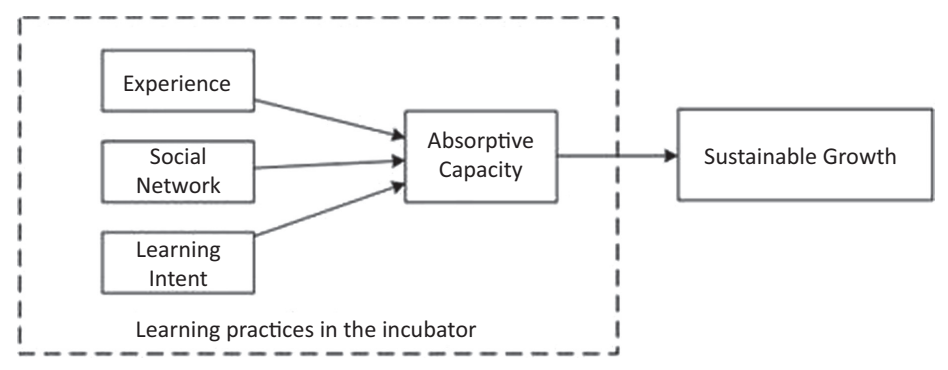

Figure 1. Learning huddles theoretical framework 
$\underset{2,3}{\text { JIUC }}$

146

participate in learning practices. As there is little research that investigates the relationship between learning typologies, absorptive capacity and sustainable growth within business incubators in China, an in-depth qualitative investigation was considered appropriate for this study (Feagin et al. 1991). In the past, when little information had been available for solving similar research issues, a qualitative approach to research design was recommended by a number of scholars (Yin 2003; Creswell, 2003; Madriz et al., 2000; Gummesson 2000).

The incubators were chosen due to their contrasting industry emphasis and similarity in incubation services, such as facilities, business training and mentoring. Established in 2014, International Maker Park (IMP) is a generalist incubator providing property support and business services for new enterprises for a variety of industry sectors. Included in IMP services are a series of value-added networking and training services in government and business policies, public interest and various degree courses. Belonging to a national incubator network of a group company, the Chengdu Building Dream Star Incubator located in the Chengdu High-tech Zone provides shared resource services, government support delivery, venture capital platform as well as training in commerce and government policy topics for various technology-based start-ups. Building Dream Star also hosts business forums and conferences for the incubatees. As the youngest of the three, the Uchen Panentertainment International Incubator specializes in research and development, talent selection, expert mentoring and training services for start-ups within the electronic entertainment (gaming) industry sector.

Using a nonrandom sample, data were collected in November 2019 via semi-structured interviews with a total of 14 people: four incubator managers and ten incubatees in business incubators in Chongqing and Chengdu. Interviews commenced with participants speaking generally about their experiences and then were asked more probing questions related to learning practices and measures of success. This approach allowed the researchers flexibility in interpreting data collected from individuals in similar working circumstances (Creswell, 2003; Guba and Lincoln 1994). Having an interview guide allowed enough structure to cover the main lines of inquiry and enough freedom to explore and probe where necessary (Patton, 2002). This also assisted with reliability, credibility and trustworthiness of the responses (Yin, 2013). The interviews lasted for approximately 40 minutes each, resulting in more than 560 hours of audio recordings. The recordings were transcribed and analyzed using an analytic map, and codes can refer to the Appendix. Category clusters and explanation building, as recommended by Yin (2003), were used to explore the data as outlined in the analytical map in Figure 2. Explanation building is the process of refining a set of ideas, in which an important aspect prompts consideration of other plausible explanations (Yin, 2003). Adopting this approach, the data were analyzed to explore the relationship between learning practices, absorptive capacity and incubatee's perception of success. The explanations also reflected the theoretical propositions discussed in the literature review. To keep the research focused, during the case analysis, constant reference was made to the original goals of the research study and the alternative explanations (Voss et al., 2002; Yin, 2003).

\section{Findings and analysis}

Table 1 shows the interview data classified by theme and sub-themes using categories from Kennett's (2013) firm-based learning practices combined with Pettersson and Götsén's (2016) knowledge acquisition process. The table shows the number of interviews where these subthemes were spoken of and as a percentage of total interviews.

\subsection{Learning practices of incubatees}

The immediate response to how incubatees seek knowledge indicates an acknowledgment of the formal training opportunities provided by the incubator. The most mentioned $(71 \%)$ 


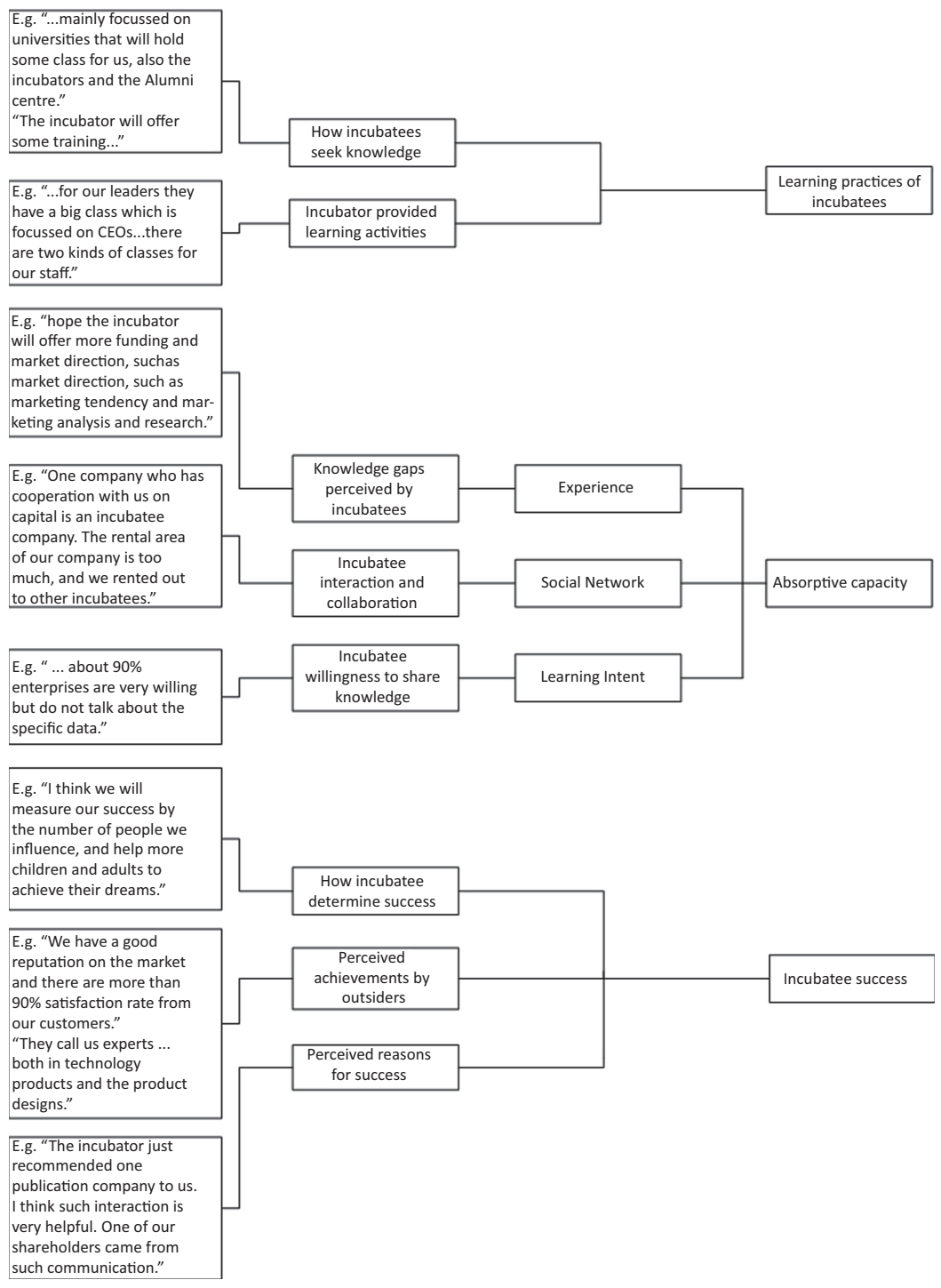

Figure 2. Analytic map

response is classroom-style business management and government policy programs. Another frequently spoken learning practice is learning from others (vicarious learning). Vicarious learning relies on individual incubatees' willingness to share knowledge (Fang et al., 2010), and this study finds a strong willingness to share knowledge, where sharing occurs when it is identified as being beneficial to the incubatees' business.

I took an example in one's discussions, and I talked to them about the present situation of our companies. One manager in another company because that manager is experienced. So, he offered me some advice. Yes. And we learned a lot from his advice. (CD Male 2) 


\begin{tabular}{llcc}
\hline Themes & Sub-themes & $\begin{array}{c}\text { Number of interviewees who } \\
\text { spoke of the theme and sub- } \\
\text { theme }\end{array}$ & $\begin{array}{c}\text { \% of the } \\
\text { total (14) }\end{array}$ \\
\hline $\begin{array}{l}\text { Structured formal } \\
\text { incubator provided }\end{array}$ & $\begin{array}{l}\text { Classroom style business } \\
\text { management and government } \\
\text { learning }\end{array}$ & 10 & 71 \\
& $\begin{array}{l}\text { Univers training programs } \\
\text { Specific industry related training }\end{array}$ & 5 & \\
Unstructured informal & Roundtables and forums & 3 & 35 \\
training & Internet and WeChat forums & 8 & 21 \\
Unstructured vicarious & Alumni mentoring and coaching & 6 & 42 \\
learning & Interaction with other incubatees & 3 & 21 \\
Unstructured searching & External research and development & 8 & 57 \\
and noticing & Virtual simulation & 5 & 36 \\
\hline
\end{tabular}

The various types of learning practices undertaken in business incubators are summed up by one interviewee who spoke of all three themes.

There are three ways. The incubators will go into the enterprises and will do some research and to know the situation of the companies. The second one is to take the company out to see how others get success and the third one is they will hold some lectures on training. And the most important one they will share some resources together. Lecturer and roundtable communication. We have a WeChat group chat and they will announce the time for us and who is willing to go and you can apply for it. (CQ Male 2)

Others respond by recognising that they also seek knowledge by observing and experimenting.

I always visit some experiment rooms of some research base and I will see how the teachers and the students do their experiments and I will learn from them, and they are also the customers of our company. (CQ Male 1)

For the $5 \mathrm{G}$, we have cooperation with a very famous mobile phone company Ericsson. And we learn together and develop together, we do some research together. It helps us. (CD Male 2)

\subsection{Absorptive capacity of incubatees}

4.2.1 Experience (knowledge gaps perceived by incubatees). According to Staniewski (2016), knowledge becomes competence, which in turn leads to experience that helps establish a competitive advantage. Prior research also demonstrates that managers' knowledge is derived from their experience and without managers' cumulative experience one firm cannot maintain a competitive advantage (Augier and Teece, 2009). Interviewees rely on business incubator managers' expertise to help build their specific business knowledge and experience but many express that the incubator managers' need to support incubatees' specific business knowledge development. For example,

There is no specific knowledge to us and maybe they offer some training, but it is not just focused on our pottery industry. (CQ Male 3)

Most managers and leaders of the incubatees are young people and have no experience so I hope there are more training sessions for us and we learn more specific skills. (CQ Female 2)

We major in food, and if we can look into further we may need some nutrition knowledge but we have no such knowledge. (CQ Male 2) 
The incubatees express their intention to acquire market intelligence knowledge specific for their business-related industry, for example:

I hope the incubator can offer more funding and market direction information, such as marketing tendency and marketing analysis and research. (CD Male 4)

Therefore, to narrow the knowledge and experience gap the incubatees may need more than the learning offered through the business incubator and seek specific business knowledge externally.

4.2.2 Social network (incubatee interaction and collaboration). Incubators present a form of organizational network (Chan and Lau, 2005) and act as hubs (Dhanaraj and Parkhe, 2006) that enable incubatees to learn from others both informally and formally. Formal interaction can occur during training or other planned business gatherings, of which interviewees express is provided frequently. Such as,

We study together and take the training together. We will also have some communication on the policies and how to understand and use the policies, and I think they are very helpful. (CQ Male 2)

There are many kinds of interaction. We will have some practical training. There are also some camps on marketing or investment... In many different activities, we can communicate with the same field incubatees and have some brainstorming together. (CQ Female 1)

Informal interaction may occur at work-related social occasions, such as working luncheons, functioning as a bridge for acquiring and exchanging knowledge in Chinese culture (Peng and Luo, 2000). These informal occasions often alleviate communication barriers and help with the flow of discussion. For example,

In China, having dinner together is very common in business. Although we have no specific links together, we can know what others are doing through that. We can realize what resources we can share with each other in the communication process. (CD Male 1)

We have many interactions with other members, such as having lunch at the restaurant...I have some interaction with the boss here, and also we have communication with the company which rents some equipment for us. (CQ Male 1)

Similarly, incubatees' informal interactions may lead to future collaboration, benefiting the sustainable growth of the incubatees. Also, collaboration among incubatees, the incubator managers and even the graduated incubatees can increase incubatees' knowledge and market awareness (Rubin et al., 2015). For example,

One company who has cooperation with us on capital is an incubatee company. Also since the rental area of our company is too big, we rented out to other incubatees. (CD Male 1)

There is a program called Innovation Street Program. We collaborate in this program and we introduce others to help them to learn. (CQ Female 1)

In Chinese culture, these formal and informal interactions are ways of building Guanxi, which is often regarded as a critical resource to help firms build and sustain their competitive advantage (Luo and Park, 2001). Therefore, doing business in China required investment in resources to initiate formal and informal connections (Chen et al., 2013). Soetanto and Jack (2016) also propose that networking during incubation is positively related to the performance of the incubatees even after postincubation. One interviewee discussed how the incubator management used informal interaction as a learning mechanism by stating that

After roundtable discussions, we cook in the kitchen and make dumplings. Our concept is to share together and establish together so we learn from each other and grow with each other. (CQ Male 5) 
JIUC 2,3

Scillitoe and Chakrabarti (2010) explain that the existence of networking interactions and counseling interactions in business incubators, which make up the structural and relational dimensions of social capital (Nahapiet and Ghoshal, 1998; Scillitoe and Chakrabarti, 2010). These networking interactions are very critical for the survival and success of the incubatees (Lyons, 2000) and may improve incubatees' social capital and their performance (Hughes et al., 2007).

4.2.3 Learning Intent (incubatee willingness to share knowledge). Another key aspect of absorptive capacity is the intention to learn. According to Nonaka (1994), learning intent may influence the knowledge creation process. In both the Chongqing and Chengdu incubators, most of the incubatees express their willingness learn and share knowledge with others. For example,

In fact, most enterprises are very willing to communicate and share their skills with others. If they must take data here, more than $95 \%$ are willing to do this. (CQ Female 1)

Incubatees have willingness to share knowledge because there is unlikely to be competition between incubatees in the same incubator if the incubator is not industry specialized.

They are very willing to share such things. Actually, in our field, there are not so many competitive companies in this incubator. (CQ Male 3)

Baker and Sinkula (1999) also agreed that higher learning orientation led to better learning and performance. And according to the interview, those who have more learning intent would have more opportunities to establish better social networks and accumulate more social capital, which will, in turn, lead to better performance than their counterparts in the long run. For example one interviewee's willingness to share leads to a business opportunity.

Many programs are very comprehensive, not just about saving water, also about saving electricity and heating energy. Different companies specialize in saving different energy, so if we communicate more there will be more cooperation opportunities for us. (CQ Female 2)

Therefore, absorptive capacity functions as a key variable deciding the business success of Chinese incubatees in the learning "huddles", since the managerial experience, social network and learning intent all positively influence the incubatees' absorptive capacity.

\subsection{Incubatee success}

Business success is usually defined as survival, growth and profitability (Pettersson and Götsén, 2016); however, concerning incubatees' success, survival rate and financial growth are used most widely (Hackett and Dilts, 2004) and consideration for incubatee goals and strategies is significant (Miettinen, 2016). The interviews attempt to uncover the latter as a more practical way to assess the business success of Chinese incubatees, exploring from two perspectives: how incubatees determine and attribute their success and how the stakeholders perceive the achievements of the incubatees. Table 2 shows the number of times a specific determinate of success, theme and sub-theme, is mentioned by incubatees.

4.3.1 How incubatees determine the success. Table 2 indicates that whilst the incubatees described determinants of success very differently, all incubatees express their goals in terms of growth in the national and global market and influence in the community. For example, the determinants of success varied from reaching and realizing business plans along with revenue and profit to reach of product in the market (70\%), market share or brand impact or being listed on the stock exchange $(100 \%)$ and the corporate social responsibility outputs $(50 \%)$.

... The third stage: the recognition of customers and business revenues. (CD Male 1) 


\begin{tabular}{|c|c|c|c|c|}
\hline Themes & Sub-themes & $\begin{array}{l}\text { Number of incubatees, only } \\
\text { interviewees who spoke of the } \\
\text { theme and sub-theme }\end{array}$ & $\begin{array}{l}\% \text { of the } \\
\text { total }(10)\end{array}$ & $\begin{array}{r}\text { Learning } \\
\text { huddles }\end{array}$ \\
\hline \multirow{3}{*}{$\begin{array}{l}\text { Determined } \\
\text { success by } \\
\text { incubatees }\end{array}$} & Business profit & 7 & 70 & \\
\hline & $\begin{array}{l}\text { Growing network/market shares/ } \\
\text { brand impact }\end{array}$ & 10 & 100 & \\
\hline & $\begin{array}{l}\text { Corporate social responsibility/ } \\
\text { reputation }\end{array}$ & 5 & 50 & 151 \\
\hline \multirow{4}{*}{$\begin{array}{l}\text { Perceived } \\
\text { achievements }\end{array}$} & Customer satisfaction & 5 & 50 & \\
\hline & $\begin{array}{l}\text { Regulatory approval/government } \\
\text { support }\end{array}$ & 9 & 90 & \\
\hline & $\begin{array}{l}\text { Industrial/business partner } \\
\text { recognition }\end{array}$ & 9 & 90 & \\
\hline & Team cohesion & 10 & 100 & \\
\hline \multirow[t]{2}{*}{$\begin{array}{l}\text { Perceived reasons } \\
\text { for the success }\end{array}$} & $\begin{array}{l}\text { Learning huddle through formal } \\
\text { and informal learning, networking } \\
\text { and social interaction }\end{array}$ & 9 & 90 & $\begin{array}{r}\text { Table 2. } \\
\text { Perceived } \\
\text { determinants of }\end{array}$ \\
\hline & $\begin{array}{l}\text { Facilitate the development of } \\
\text { incubatee's social capital }\end{array}$ & 8 & 80 & $\begin{array}{r}\text { business incubatee } \\
\text { success }\end{array}$ \\
\hline
\end{tabular}

Achievements in the non-profit areas, we go to 150 schools in rural areas to offer lectures for them. I think we will measure our success by the number we influence and help more children and adults to achieve their dreams. (CQ Female 1)

The incubatees agree that it is difficult to use profit as a measure of success because in the early stage of the set up they may have some loss. This is expressed as follows:

For the short and the medium-term objectives, we hope we can stand in Chongqing and have an influence on the whole southwestern China and then to the whole of China and then one day go to the world. (CQ Female 1)

4.3.2 Perceived achievements. Perceived prestige or enhanced reputation are found to have positive effects on the incubatees (Westhead and Storey, 1997; Studdard, 2006). The perception of stakeholders is very important to reflect the success of incubatees and will become part of the self-assessment indicators in the long term when reinforced by psychological cognition. Some incubatees are recognized by customers $(50 \%)$, business partners $(90 \%)$, employees $(100 \%)$ or even the government $(90 \%)$.

We have a good reputation in the market and there are more than $90 \%$ satisfaction rates from our customers. (CQ Male 2)

The R\&D in Game Development has a long process. . .Only when the R\&D in Game Development reaches a certain stage and is taken out to communicate with outsiders, the design and play methods are recognized by industrial partners more frequently. (CD Male 1)

Mian et al. (2016) mention that only 15\% of business incubation empirical studies explore the assessment of incubator performance. Peters et al. (2004) find that the number of graduates is a rough way to measure the success of incubators since graduation actually causes an instant negative effect on the survival of the firm in the postincubation time (Schwartz, 2009). Therefore, how the incubatees determine their success and how the stakeholders perceive an incubatee's achievement could be a more reasonable and reliable assessment of success.

4.3.3 Perceived reasons for the success. The incubatees spoke of their success being attributed to the learning huddle through vicarious informal learning, networking and social interaction supported by the incubator $(90 \%)$. 
$\underset{2,3}{\text { JIUC }}$

152
I think such interaction is very helpful. One of our shareholders came from such communication. (CD Male 1)

I have got a lot of training from the incubators and I have learnt a lot and there is some training on specific fields like our fields which can save energy and it gives me a platform and opportunity to meet more people in our fields because you know our field is not so popular. (CQ Female 2)

Incubatees also felt that when incubators facilitate the development of incubatees' social capital, it is manifestation such as an ability of actors (incubatees) to use their social resources in social networks (Zhu, 2005), and then they are more likely to succeed (80\%).

The incubator should help the incubatees to build some links with other companies and with societies. By such links, it can promote the development of the companies... (CD Male 5)

\section{Conclusion and implications}

Although many studies have been conducted to determine operating models for business incubation (Hausberg and Korrek, 2020), the assessment of business incubation success (Phillips, 2002; Dee et al., 2011) and the importance of constructing theories concerning business incubation (Patton et al., 2009; Marlow and McAdam, 2012), few scholars have used matched measures of success with incubators goals (Bergek and Norrman, 2008; Miettinen, 2016) to assess the effectiveness of business incubation. Also, relatively few studies have focused on the relationship between incubatees' learning practices and the likelihood of success, especially in the Chinese incubator context. Redding and Rowley (2017) suggest that further research is required to explore how human capital (individual knowledge) and social capital (collective knowledge) are developed in the process of entrepreneurial learning.

By examining the three propositions, (1) a typology of learning practices is useful as a mechanism for further studies in business incubators (2) absorptive capacity of incubatees is influenced by their experience, social networks and learning intent and (3) absorptive capacity facilitates positive effects on the sustainable growth of incubatees, this study finds that incubatees perceive that their absorptive capacity (ability to value, assimilate and apply new knowledge) is enhanced through vicarious informal learning practices that promotes access to networks and thereby uses social capital to improve their likelihood of success. This is also confirmed in Bliemel et al.'s (2019) study of accelerator programs, which indicate that a key contributor to the success of entrepreneurial programs is the access to a network of experts including mentors, guest speakers and professional service providers.

In regard to proposition one, this study finds that it is possible to construct a typology of learning practices based on extending the types of common firm-based learning practices identified by Kennett (2013) and business incubation learning identified in the literature by Fang et al. (2010) and Pettersson and Götsén (2016) to include collective learning practices. Figure 3 provides a diagrammatic view of the proposed typology that could be used as a basis for future studies of learning practices in business incubators.

The interviews with incubatees also confirm Volberda et al.'s (2010) antecedents of absorptive capacity where the experience of the managerial levels, interorganizational network and learning intent of the incubatees is critical for influencing absorptive capacity of the Chinese incubatees. The interviewees' learning experience is similar to that described by Digenti (1999). The interaction of two or more people engaged in value-creating activities based on improving, practicing and transferring learning skills both within the groups and to the organization or groups of organizations to which the group belongs. (p. 45). The study also finds that through vicarious informal learning, incubatees form social networks attached to the incubator, which in turn leads to their social capital development. Since the incubator serves as a learning context socially embedded by incubatees, it can bring better collective 


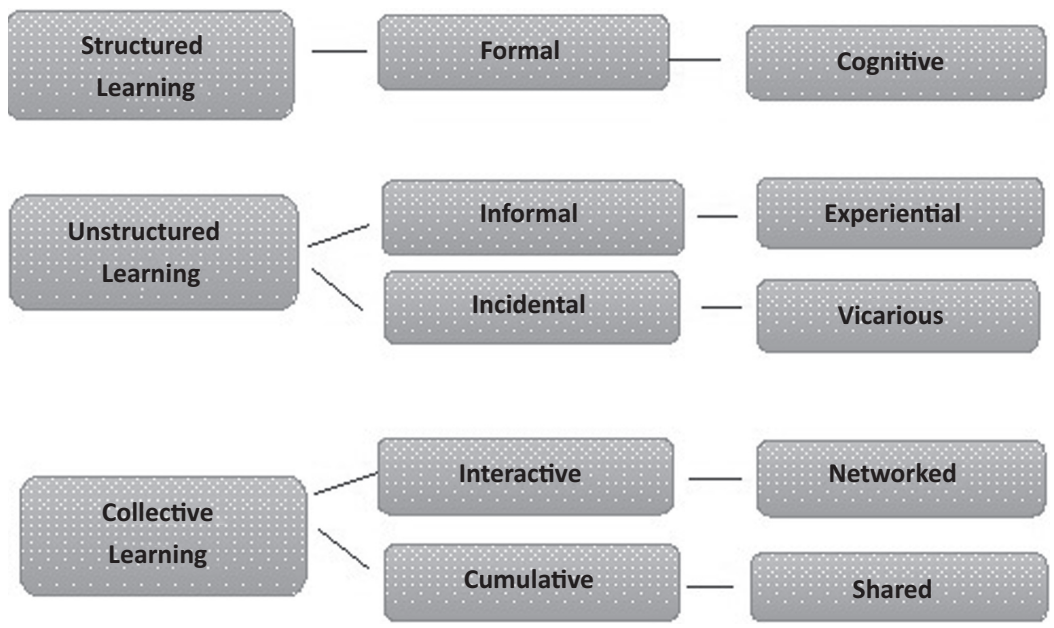

learning intentions and capability building achievement, and thereby better performance (Bliemel et al., 2019; Håkansson and Johason, 2001).

The incubatees express that their success in terms of reputation, market growth and expertise is a consequence of access to incubator "learning huddles", collective learning and networks that result in community cluster capital, similar to that uncovered by Bliemel et al. (2019) in their study of accelerator clusters. Together the incubatees assist each other in developing the knowledge and expertise required to succeed in their business. In this way, the study reaffirms the proposition that absorptive capacity may facilitate positive effects on the sustainable growth of incubatees. These findings demonstrate the McCarthy and Garavan's (2008) and Bliemel et al.'s (2019) view that incubators are ecosystems for collective learning, the ability to share information so efficiently that the ideas of individuals can be stored within the collective memory of communities and can accumulate knowledge through generations of new businesses. Such knowledge, known as collective learning, is created in the form of norms, discourse and strategies that guide future action. In both the Chongqing and Chengdu incubators, the incubatees "huddle" together to learn collectively and grow fast.

However it is often difficult to determine if the incubator determines an incubatees success or whether the incubatee already had the capacity to succeed. An incubatee spoke of this using the analogy of what comes first - the chicken or the egg.

The features of Chinese incubators are different from foreign countries. We are more focused on the incubating process. Sometimes the incubators when they enter, they new EGGS but some of them are a little CHICK and this comes to a very old question which comes first? Explained in three aspects. The first one - some companies they belong to eggs and some are chickens. Not whether you are eggs and chicken. There is one condition you need. The temperature. If there is a kind of machine or system that can adjust the temperature, it would be very helpful, and it would help the incubator promotion [success]. (CD Male 5)

Business incubators and their networks offer a nurturing shared learning environment, which is suitable for incubatees to collectively absorb knowledge at the early stage of their life cycle and improve their likelihood of sustainable growth. The study replication and extension of the work of Garavan and Carbery (2012), Volberda et al. (2010) and Bliemel et al. (2019) to add evidence that business incubator programs provide learning huddles that enhance collective absorptive capacity through interactive mechanisms where individual knowledge 
JIUC 2,3

is shared, disseminated and further developed through relational and belonging synergies, thus enhance the social efficiency by way of increasing their social capital.

This study has limitations in sample size and design. The explorative case study approach uses a nonrandom case selection of three incubators in Chongqing and Chengdu and has a limited number of interviewees which may lack representation of the general Chinese business incubation population and may not sufficiently be generalized beyond the sample itself.

Empirically, this study adds to the discussion on how collective learning practices facilitate absorptive capacity and build social capital, which in turn improves incubatees' chance of sustainable growth and as such the authors hope that the learning practice's typology and how incubatees determine their success stimulates further research for measuring the likelihood of incubatees sustainable growth. Since this study is limited to a Chinese context, it is also hoped that future researchers use the typology of business incubator learning practices to explore cross-culture variables as these may influence the business incubation operations and performance.

\section{References}

Augier, M. and Teece, D.J. (2009), "Dynamic capabilities and the role of managers in business strategy and economic performance", Organization Science, Vol. 20 No. 2, pp. 410-421.

Baker, W.E. and Sinkula, J.M. (1999), "The synergistic effect of market orientation and learning orientation on organizational performance", Journal of the Academy of Marketing Science, Vol. 27 No. 4, pp. 411-427.

Baral, S. (2013), "The challenge of attaining sustainable growth-a case study on rural micro finance in Gujarat", Arth Prabhand: A Journal of Economics and Management, Vol. 2 No. 2, pp. 1-11.

Bearse, P. (1998), "A question of evaluation: NBIA's impact assessment of business incubators", Economic Development Quarterly, Vol. 12 No. 4, pp. 322-333.

Belso-Martinez, J.A., Molina-Morales, F.X. and Mas-Verdu, F. (2013), "Combining effects of internal resources, entrepreneur characteristics and KIS on new firms", Journal of Business Research, Vol. 66 No. 10, pp. 2079-2089.

Bergek, A. and Norrman, C. (2008), "Incubator best practice: a framework", Technovation, Vol. 28 Nos 1-2, pp. 20-28.

Bierly, P.E. III, Damanpour, F. and Santoro, M.D. (2009), "The application of external knowledge: organizational conditions for exploration and exploitation", Journal of Management Studies, Vol. 46, pp. 481-509.

Bliemel, M., Flores, R., De Klerk, S. and Miles, M.P. (2019), “Accelerators as start-up infrastructure for entrepreneurial clusters", Entrepreneurship and Regional Development, Vol. 31 Nos 1-2, pp. 133-149.

Böhringer, A. (2006), In Knowledge Specialization and Transfer: A Knowledge Based Framework for Business Incubation, DRUID Summer Conference, Copenhagen.

Bøllingtoft, A. (2012), "The bottom-up business incubator: leverage to networking and cooperation practices in a self-generated, entrepreneurial-enabled environment", Technovation, Vol. 32 No. 5, pp. 304-315.

Bøllingtoft, A. and Ulhøi, J.P. (2005), "The networked business incubator-leveraging entrepreneurial agency?", Journal of Business Venturing, Vol. 20 No. 2, pp. 265-290.

Burnett, H.H.M. (2009), Exploring the Parameters for the Optimum Funding of Australian Incubators from an Incubator Manager Perspective, Australian Graduate School of Entrepreneurship, Faculty of Business and ....

Cantù, C. (2017), "Entrepreneurial knowledge spillovers: discovering opportunities through understanding mediated spatial relationships", Industrial Marketing Management, Vol. 61, pp. $30-42$. 
Chan, K. and Lau, T. (2005), "Assessing technology incubator programs in the science park: the good, the bad and the ugly", Technovation, Vol. 25 No. 10, pp. 1215-1228.

Chen, C.C., Chen, X.P. and Huang, S. (2013), "Chinese guanxi: an integrative review and new directions for future research", Management and Organization Review, Vol. 9 No. 1, pp. 167-207.

Choi, Y. and Jin, J. (2015), "Is the web marketing mix sustainable in China? The mediation effect of dynamic trust", Sustainability, Vol. 7 No. 10, pp. 13610-13630.

Cohen, W.M. and Levinthal, D.A. (1990), "Absorptive capacity: a new perspective on learning and innovation”, Administrative Science Quarterly, pp. 128-152.

Cohen, S., Fehder, D.C., Hochberg, Y.V. and Murray, F. (2019), “The design of startup accelerators”, Research Policy, Vol. 48 No. 7, pp. 1781-1797.

Creswell, J.W. (2003), Research Design: Qualitative, Quantitative and Mixed Method Approaches, Sage Publications, London.

Cully, M. (2005), "Employer-provided training: findings from case studies-at a glance", Education, Vol. 92 No. 72.9 , pp. $478-80$.

Dee, N.J., Livesey, F., Gill, D. and Minshall, T. (2011), "Incubation for growth", Research Summary, Vol. 11, pp. 3-40.

Dhanaraj, C. and Parkhe, A. (2006), "Orchestrating innovation networks", Academy of Management Review, Vol. 31 No. 3, pp. 659-669.

Digenti, D. (1999), "Collaborative learning: a core capability for organizations in the new economy", Reflections, Vol. 1 No. 2, pp. 45-57.

Ebers, M. and Maurer, I. (2014), "Connections count: how relational embeddedness and relational empowerment foster absorptive capacity", Research Policy, Vol. 43 No. 2, pp. 318-332.

Fang, S.C., Tsai, F.S. and Lin, J.L. (2010), "Leveraging tenant-incubator social capital for organizational learning and performance in incubation programme", International Small Business Journal, Vol. 28 No. 1, pp. 90-113.

Feagin, J., Orum, A. and Sjoberg, G. (Eds) (1991), A Case for Case Study, University of North Carolina Press, Chapel Hill, NC.

Ferreras-Méndez, J.L., Newell, S., Fernández-Mesa, A. and Alegre, J. (2015), "Depth and breadth of external knowledge search and performance: the mediating role of absorptive capacity", Industrial Marketing Management, Vol. 47, pp. 86-97.

Garavan, T.N. and Carbery, R. (2012), "A review of international HRD: incorporating a global HRD construct", European Journal of Training and Development, Vol. 36, pp. 129-157.

Guba, E.G. and Lincoln, Y.S. (1994), "Competing paradigms in qualitative research", Handbook of Qualitative Research, Vol. 2 Nos 163-194, p. 105.

Gummesson, E. (2000), Qualitative Methods in Management Research, Sage Publications, London.

Gupta, A.K. and Govindarajan, V. (2000), "Knowledge flows within multinational corporations", Strategic Management Journal, Vol. 21 No. 4, pp. 473-496.

Håkansson, H. and Johanson, J. (2001), Business Network Learning, Elsevier, London.

Hackett, S.M. and Dilts, D.M. (2004), "A systematic review of business incubation research", The Journal of Technology Transfer, Vol. 29 No. 1, pp. 55-82.

Hansen, M.T., Chesbrough, H.W., Nohria, N. and Sull, D.N. (2000), "Networked incubators", Harvard Business Review, Vol. 78 No. 5, pp. 74-84.

Haugh, H. (2020), "Call the midwife! Business incubators as entrepreneurial enablers in developing economies", Entrepreneurship and Regional Development, Vol. 32 Nos 1-2, pp. 156-175.

Hausberg, J.P. and Korreck, S. (2020), "Business incubators and accelerators: a co-citation analysisbased, systematic literature review", The Journal of Technology Transfer, Vol. 45, pp. 151-176.

Hedberg, B. (1981), "How organizations learn and unlearn", Handbook of Organizational Design No. 1, pp. 3-27. 
JIUC 2,3

Hughes, M., Ireland, R.D. and Morgan, R.E. (2007), "Stimulating dynamic value: social capital and business incubation as a pathway to competitive success", Long Range Planning, Vol. 40 No. 2, pp. 154-177.

Jiang, X. and Li, Y. (2009), "An empirical investigation of knowledge management and innovative performance: the case of alliances", Research Policy, Vol. 38 No. 2, pp. 358-368.

Kahrović, E. (2020), "Entrepreneurial universities and intermediary organizations as a success factor in SMEs: literature review”, Ekonomika Preduzé́a, Vol. 68 Nos 3-4, pp. 229-247.

Kakabadse, N., Karatas-Ozkan, M., Theodorakopoulos, N., McGowan, C. and Nicolopoulou, K. (2020), "Business incubator managers' perceptions of their role and performance success: role demands, constraints, and choices”, European Management Review, Vol. 17 No. 2, pp. 485-498.

Kennett, G. (2013), "The impact of training practices on individual, organisation, and industry skill development”, Australian Bulletin of Labour, Vol. 39 No. 1, p. 112.

Kim, C. and Inkpen, A.C. (2005), "Cross-border R\&D alliances, absorptive capacity and technology learning”, Journal of International Management, Vol. 11 No. 3, pp. 313-329.

Kiran, R. and Bose, S. (2020), "Stimulating business incubation performance: role of networking, university linkage and facilities", Technology Analysis and Strategic Management, pp. 1-15.

Lane, P.J. and Lubatkin, M. (1998), "Relative absorptive capacity and interorganizational learning", Strategic Management Journal, Vol. 19 No. 5, pp. 461-477.

Lane, P.J., Salk, J.E. and Lyles, M.A. (2001), "Absorptive capacity, learning, and performance in international joint ventures”, Strategic Management Journal, Vol. 22 No. 12, pp. 1139-1161.

Levitt, B. and March, J.G. (1988), "Organizational learning”, Annual Review of Sociology, Vol. 14 No. 1, pp. 319-338.

Luo, Y. and Park, S.H. (2001), "Strategic alignment and performance of market-seeking MNCs in China", Strategic Management Journal, Vol. 22 No. 2, pp. 141-155.

Lyons, T.S. (2000), "in building social capital for sustainable enterprise development in country towns and regions: successful practices from the United States", First National Conference on the Future of Australia's Country Towns, La Trobe University, Center for Sustainable Regional Communities, Australia, June, pp. 29-30.

Madriz, E., Denzin, N. and Lincoln, Y. (2000), Handbook of Qualitative Research, Sage Publications, California.

Manuti, A., Pastore, S., Scardigno, A.F., Giancaspro, M.L. and Morciano, D. (2015), "Formal and informal learning in the workplace: a research review", International Journal of Training and Development, Vol. 19 No. 1, pp. 1-17.

Marlow, S. and McAdam, M. (2012), "Analyzing the influence of gender upon high-technology venturing within the context of business incubation", Entrepreneurship: Theory and Practice, Vol. 36 No. 4, pp. 655-676.

McAdam, M. and McAdam, R. (2008), "High tech start-ups in University Science Park incubators: the relationship between the start-up's lifecycle progression and use of the incubator's resources", Technovation, Vol. 28 No. 5, pp. 277-290.

McCarthy, A. and Garavan, T.N. (2008), "Team learning and metacognition: a neglected area of HRD research and practice", Advances in Developing Human Resources, Vol. 10 No. 4, pp. 509-524.

Mian, S., Lamine, W. and Fayolle, A. (2016), "Technology business incubation: an overview of the state of knowledge", Technovation, Vol. 50, pp. 1-12.

Miettinen, T. (2016), A Business Incubator, Accelerator, or Coworking Space? Case Health Innovation Village at GE, available at: http://lutpub.lut.fi/bitstream/handle/10024/123437/A\%20BUSINESS $\%$ 20INCUBATOR, $\%$ 20ACCELERATOR $\% 200 R \%$ 20COWORKING $\% 20$ SPACE.pdf?isAllowed $=y \&$ sequence $=2$. 
Miller, R. (2018), "What does sustainable growth really mean?", available at: www.forbes.com/sites/ rickmiller/2018/08/16/what-does-sustainable-growth-really-mean/\#268e09367a98 (accessed 31 July 2020).

Moss, T.W., Short, J.C., Payne, G.T. and Lumpkin, G. (2011), "Dual identities in social ventures: an exploratory study", Entrepreneurship: Theory and Practice, Vol. 35 No. 4, pp. 805-830.

Myers, K., Conte, N. and Rubenson, K. (2014), Adult Learning Typology: Adult Learning and Returns to Training Project, [pdf], Social Research and Demonstration Corporation, Ottawa, available at: www.srdc.org/media/199755/adult-learning-typology.pdf (accessed 28 July 2020).

Nahapiet, J. and Ghoshal, S. (1998), "Social capital, intellectual capital, and the organizational advantage", Academy of Management Review, Vol. 23 No. 2, pp. 242-266.

Narasimhan, O., Rajiv, S. and Dutta, S. (2006), "Absorptive capacity in high-technology markets: the competitive advantage of the haves", Marketing Science, Vol. 25 No. 5, pp. 510-524.

National Bureau of Statistics of China (2020), "Statistical communique of the people's Republic of China on the 2019 national economic and social development", available at: www.stats.gov.cn/ english/PressRelease/202002/t20200228_1728917.html (accessed 28 July 2020).

Nonaka, I. (1994), “A dynamic theory of organizational knowledge creation”, Organization Science, Vol. 5 No. 1, pp. 14-37.

Patton, M.Q. (2002), "Qualitative interviewing”, Qualitative Research and Evaluation Methods, Vol. 3 No. 1, pp. 344-347.

Patton, D., Warren, L. and Bream, D. (2009), "Elements that underpin high-tech business incubation processes", The Journal of Technology Transfer, Vol. 34 No. 6, pp. 621-636.

Peng, M.W. and Luo, Y. (2000), "Managerial ties and firm performance in a transition economy: the nature of a micro-macro link", Academy of Management Journal, Vol. 43 No. 3, pp. 486-501.

Peters, L., Rice, M. and Sundararajan, M. (2004), "The role of incubators in the entrepreneurial process", The Journal of Technology Transfer, Vol. 29 No. 1, pp. 83-91.

Pettersen, I.B., Aarstad, J., Høvig, Ø.S. and Tobiassen, A.E. (2015), "Business incubation and the network resources of start-ups", Journal of Innovation and Entrepreneurship, Vol. 5 No. 1, p. 7.

Pettersson, B. and Götsén, A. (2016), "Business Incubators-the savior of startups", An Exploratory Study on Knowledge Acquisition in a Business Incubator From a Startup Perspective.

Phillips, R.G. (2002), "Technology business incubators: how effective as technology transfer mechanisms?”, Technology in Society, Vol. 24 No. 3, pp. 299-316.

Rae, D. (2000), "Understanding entrepreneurial learning: a question of how?", International Journal of Entrepreneurial Behavior and Research, Vol. 18 No. 5, pp. 603-623.

Redding, G. and Rowley, C. (2017), "Conclusion: the central role of human and social capital", Asia Pacific Business Review, Vol. 23 No. 2, pp. 299-305.

Rubin, T.H., Aas, T.H. and Stead, A. (2015), "Knowledge flow in technological business incubators: evidence from Australia and Israel", Technovation, Vol. 41, pp. 11-24.

Schwartz, M. (2009), "Beyond incubation: an analysis of firm survival and exit dynamics in the postgraduation period”, The Journal of Technology Transfer, Vol. 34 No. 4, pp. 403-421.

Schwartz, M. and Hornych, C. (2010), "Cooperation patterns of incubator firms and the impact of incubator specialization: empirical evidence from Germany", Technovation, Vol. 30 Nos 9-10, pp. 485-495.

Scillitoe, J.L. and Chakrabarti, A.K. (2010), "The role of incubator interactions in assisting new ventures", Technovation, Vol. 30 No. 3, pp. 155-167.

Simonin, B. (2004), "An empirical investigation of the process of knowledge transfer in international strategic alliances", Journal of International Business Studies, Vol. 35, pp. 407-427. 
JIUC 2,3
Soetanto, D. and Jack, S. (2016), "The impact of university-based incubation support on the innovation strategy of academic spin-offs", Technovation, Vol. 50, pp. 25-40.

Staniewski, M.W. (2016), "The contribution of business experience and knowledge to successful entrepreneurship”, Journal of Business Research, Vol. 69 No. 11, pp. 5147-5152.

Studdard, N.L. (2006), "The effectiveness of entrepreneurial firm's knowledge acquisition from a business incubator", International Entrepreneurship and Management Journal, Vol. 2 No. 2, pp. 211-225.

Szulanski, G. (1996), "Exploring internal stickiness: impediments to the transfer of best practice within the firm", Strategic Management Journal, Vol. 17 No. S2, pp. 27-43.

Taneja, H. and Chenault, K. (2019), "Building a startup that will last", Harvard Business Review, Vol. 7, pp. 23-27.

Tang, M., Walsh, G.S., Li, C. and Baskaran, A. (2019), "Exploring technology business incubators and their business incubation models: case studies from China", The Journal of Technology Transfer, pp. 1-27.

Tsai, W. (2001), "Knowledge transfer in intraorganizational networks: effects of network position and absorptive capacity on business unit innovation and performance", Academy of Management Journal, Vol. 44 No. 5, pp. 996-1004.

Uzzi, B. (1996), "The sources and consequences of embeddedness for the economic performance of organizations: the network effect", American Sociological Review, pp. 674-698.

Van Wijk, R., Jansen, J.J. and Lyles, M.A. (2008), "Inter-and intra-organizational knowledge transfer: a meta-analytic review and assessment of its antecedents and consequences", Journal of Management Studies, Vol. 45 No. 4, pp. 830-853.

Vanderstraeten, J. and Matthyssens, P. (2010), "In measuring the performance of business incubators: a critical analysis of effectiveness approaches and performance measurement systems", ICSB World Conference Proceedings, International Council for Small Business (ICSB), p. 1.

Volberda, H.W., Foss, N.J. and Lyles, M.A. (2010), "Perspective-absorbing the concept of absorptive capacity: how to realize its potential in the organization field", Organization Science, Vol. 21 No. 4, pp. 931-951.

Voss, C., Tsikriktsis, N. and Frohlich, M. (2002), "Case research in operations management", International Journal of Operations and Production Management, Vol. 22, pp. 195-219.

Westhead, P. and Storey, D.J. (1997), "Department for Education and Employment Research Report", Training Provision and the Development of Small- and Medium-sized Enterprises, HMSO.

Wu, W., Wang, H. and Wu, Y.J. (2020), "Internal and external networks, and incubatees' performance in dynamic environments: entrepreneurial learning's mediating effect", The Journal of Technology Transfer, pp. 1-27.

Yin, R.K. (2003), Case Study Research: Design and Methods, Sage Publications, London.

Yin, R.K. (2013), "Validity and generalization in future case study evaluations", Evaluation, Vol. 19 No. 3, pp. 321-332.

Zahra, S.A. and George, G. (2002), "Absorptive capacity: a review, reconceptualization, and extension”, Academy of Management Review, Vol. 27 No. 2, pp. 185-203.

Zhang, Y., Zhou, X. and Lei, W. (2017), "Social capital and its contingent value in poverty reduction: evidence from Western China”, World Development, Vol. 93, pp. 350-361.

Zheng, W., Xu, M., Chen, X. and Dong, Y. (2017), "Who is shaping entrepreneurial experience? A multiple case study of Chinese entrepreneurial learning", Management Decision, Vol. 55 No. 7 , pp. 1394-1409.

Zhu, G.H. (2005), Economic Sociology, Fudan University Press, Shanghai (In Chinese). 


\section{Further reading}

Allan, D. and Bazan, E. (1990), Value Added Contributions of Pennsylvania's Business Incubators to Tenant Firms and Local Economics, Appalachian Regional Commission and the Pennsylvania Department of Commerce, State College, PA.

Allen, D.N. and McCluskey, R. (1991), "Structure, policy, services, and performance in the business incubator industry", Entrepreneurship: Theory and Practice, Vol. 15 No. 2, pp. 61-77.

Arnold, V., Clark, N., Collier, P.A., Leech, S.A. and Sutton, S.G. (2004), "Explanation provision and use in an intelligent decision aid", Intelligent Systems in Accounting, Finance and Management: International Journal, Vol. 12 No. 1, pp. 5-27.

Bergh, P., Thorgren, S. and Wincent, J. (2011), "Entrepreneurs learning together: the importance of building trust for learning and exploiting business opportunities", International Entrepreneurship and Management Journal, Vol. 7 No. 1, pp. 17-37.

Hackett, S.M. and Dilts, D.M. (2008), "Inside the black box of business incubation: study B — scale assessment, model refinement, and incubation outcomes", The Journal of Technology Transfer, Vol. 33 No. 5, pp. 439-471.

Kostopoulos, K., Papalexandris, A., Papachroni, M. and Ioannou, G. (2011), "Absorptive capacity, innovation, and financial performance", Journal of Business Research, Vol. 64 No. 12, pp. 1335-1343.

Lalkaka, R. (2002), "Technology business incubators to help build an innovation-based economy", Journal of Change Management, Vol. 3 No. 2, pp. 167-176.

Williamson, O.E. (1975), Markets and Hierarchies, SSRN, New York, NY, p. 2630.

\section{Appendix}

\begin{tabular}{lllll}
\hline Incubator location & Gender & Interviewee type & Business field & Coding \\
\hline Chongqing & Male & Incubatee manager & Bio-technology & CQ Male 1 \\
& Male & Incubatee manager & Food processing & CQ Male 2 \\
& Male & Incubatee manager & Ceramics & CQ Male 3 \\
& Female & Incubatee manager & Vocational training company & CQ Female 1 \\
& Female & Incubatee manager & Environmental water management & CQ Female 2 \\
& Male & Incubator manager & - & CQ Male 4 \\
& Male & Incubator manager & - & CQ Male 5 \\
Chengdu & Male & Incubatee manager & Phone batteries & CD Male 1 \\
& Male & Incubatee manager & Technology & CD Male 2 \\
& Male & Incubatee manager & Decor & CD Male 3 \\
& Male & Incubatee manager & Electric company & CD Male 4 \\
& Male & Incubatee manager & Environmental protection & CD Male 5 \\
& Male & Incubator manager & - & CD Male 6 \\
& Male & Incubator manager & - & CD Male 7
\end{tabular}

Table A1.

Incubatee and incubator management demographic characteristic and interview codes

\section{Corresponding author}

Alex Maritz can be contacted at: a.maritz@latrobe.edu.au

For instructions on how to order reprints of this article, please visit our website:

www.emeraldgrouppublishing.com/licensing/reprints.htm

Or contact us for further details: permissions@emeraldinsight.com 